\title{
ANALISIS TINGKAT STRES MAHASISWA TERHADAP PEMBELAJARAN DARING PADA MATA KULIAH STATISTIK BISNIS DI PENDIDIKAN VOKASI
}

\author{
Hutomo Atman Maulana1, Rosada Dwi Iswari² \\ ${ }^{1}$ Administrasi Bisnis Internasional, Politeknik Negeri Bengkalis, email: \\ hutomomaulana@polbeng.ac.id \\ ${ }^{2}$ Psikologi, Fakultas Kedokteran, Universitas Sriwijaya, email: \\ rd.iswari@fk.unsri.ac.id
}

\begin{abstract}
This study aimed to analyze undergraduate student's stress level due to online learning of statistics for business course at vocational education during the corona virus pandemic (COVID-19). This research was a qualitative descriptive study. The population in this study was all of the students of the Applied Undergraduate Program Department of International Business Administration of Politeknik Negeri Bengkalis. The samples were taken by using purposive sampling techniques that only focused on students who where taking statistics for business course since enacted online learning due to the COVID-19 pandemic. The data was collected by using online questionnaires and in -depth interviews with the students to get more detailed information. The data analysis technique used in this study was a a qualitative analysis consisting of data collection, data reduction, data presentation, and conclusion. The result showed that online learning of statistics for business course caused 3\% of the student having stress level in extremely severe categories, $13 \%$ in severe categories, $8 \%$ in moderate categories, $24 \%$ in mild categories, and $52 \%$ in normal categories. The stress level experienced by student were influenced by the gender, while the age of the students under range of 17 -20 years old did not affect stress levels.
\end{abstract}

Keywords: undergraduate student's stress level, online learning, vocational education.

\begin{abstract}
ABSTRAK
Penelitian ini bertujuan untuk mengetahui tingkat stres mahasiswa terhadap pembelajaran daring pada mata kuliah di pendidikan vokasi yang dilakukan selama masa pandemi virus corona (COVID-19). Penelitian ini merupakan penelitian deskriptif kualitatif. Populasi pada penelitian ini adalah seluruh mahasiswa program sarjana terapan Jurusan Administrasi Niaga Politeknik Negeri Bengkalis. Sampel diambil dengan menggunakan teknik purposive sampling yang hanya berfokus pada mahasiswa yang mendapatkan pembelajaran daring pada mata kuliah statistik bisnis sejak diberlakukannya pembelajaran daring karena pandemi COVID-19. Data dikumpulkan dengan menggunakan kuesioner secara daring dan wawancara mendalam kepada beberapa mahasiswa untuk mendapatkan informasi yang lebih
\end{abstract}


mendetail. Teknik analisis data yang digunakan dalam penelitian ini adalah analisis kualitatif yang terdiri atas pengumpulan data, reduksi data, penyajian data, dan penarikan kesimpulan. Hasil penelitian ini menunjukkan bahwa pembelajaran daring mata kuliah statistik bisnis mengakibatkan 3\% mahasiswa memiliki tingkat stres kategori sangat berat, $13 \%$ kategori berat, $8 \%$ kategori sedang, 24\% kategori ringan, dan 52\% dalam kategori normal. Tingkat stres yang dialami mahasiswa dipengaruhi oleh jenis kelamin mahasiswa, sedangkan usia mahasiswa dengan rentang usia 17-20 tahun tidak mempengaruhi tingkat stres.

Kata Kunci: tingkat stres mahasiswa, pembelajaran daring, pendidikan vokasi.

\section{PENDAHULUAN}

Pada masa penyebaran virus corona (COVID-19) yang terjadi saat ini ternyata menimbulkan dampak tersendiri pada sektor pendidikan di Indonesia. Penyebaran COVID-19 yang begitu cepat menciptakan kekhawatiran bagi Pemerintah, khususnya Kementerian Pendidikan dan Kebudayaan, kalangan orang tua dan peserta didik, serta para tenaga pengajar, yaitu dengan keluarnya Surat Edaran Dirjen Dikti Kementerian Pendidikan dan Kebudayaan Nomor 1 Tahun 2020 Tentang Pencegahan Penyebaran Corona Virus Disease (COVID19) di Perguruan Tinggi. Hal inilah yang kemudian membuat sejumlah perguruan tinggi harus menghentikan proses kegiatan belajar mengajar (KBM) secara tatap muka di dalam kelas dan menyelenggarakan pembelajaran jarak jauh. Pembelajaran secara daring dianggap menjadi solusi terbaik terhadap kegiatan belajar mengajar di tengah pandemi COVID-19. Pembelajaran secara daring (dalam jaringan) merupakan penerapan dari pendidikan jarak jauh. Pembelajaran dengan cara ini bertujuan untuk menjaga kesehatan dan keselamatan peserta didik. Oleh karena itu, pembelajaran daring akan memberikan kesempatan peserta didik untuk tetap dapat mengikuti suatu pelajaran atau mata kuliah tertentu tanpa adanya batasan jarak dan waktu.

Meski telah disepakati, pembelajaran daring masih menimbulkan kontroversi. Bagi tenaga pengajar, pembelajaran daring hanya efektif untuk penugasan, sedangkan untuk membuat peserta didik memahami materi pembelajaran secara daring dinilai sulit. Selain itu, kemampuan teknologi dan ekonomi setiap peserta didik berbeda-beda. Tidak semua peserta didik memiliki fasilitas yang menunjang kegiatan pembelajaran daring. Koneksi internet yang tidak memadai, perangkat yang tidak mendukung, dan kuota 
internet yang mahal menjadi penghambat pembelajaran daring. Namun, pembelajaran harus terus berlanjut. Setiap penyelenggara pendidikan memiliki kebijakan masing-masing dalam menyikapi aturan ini. Beberapa institusi pendidikan tinggi memberikan subsidi kuota internet kepada mahasiswa demi terselenggaranya pembelajaran daring.

Meski terdapat beberapa institusi pendidikan tinggi di Indonesia yang sudah siap melakukan pembelajaran daring, hadirnya COVID-19 menunjukkan institusi pendidikan tinggi yang tidak siap dalam menerapkan sistem pembelajaran daring jumlahnya lebih banyak. Misalnya, pemanfaatan teknologi pembelajaran daring masih didominasi oleh universitas di kota besar karena kapasitas finansial dan ketersediaan sistem pembelajaran digital ( $e$ learning) yang lebih baik dibandingkan kampus kecil di daerah rural. Selain itu, tidak sedikit jumlah pendidik yang masih kesulitan menggunakan teknologi pembelajaran daring baik itu menggunakan e-learning atau pun platform lain dari pihak ketiga seperti Zoom, Google Classroom, dan CloudX. Hal ini membuat pembelajaran daring berlangsung hanya memberikan tugas secara jarak jauh tanpa ada umpan balik maupun interaksi dengan peserta didik. Sehingga jika dilakukan secara terus-menerus dapat mengakibatkan meningkatnya tingkat stres peserta didik.

Beberapa penelitian terkait dengan pembelajaran daring telah banyak dilakukan. Tantri (2018) melakukan penelitian terhadap kehadiran sosial dalam pembelajaran daring berdasarkan sudut pandang pembelajar pendidikan terbuka dan jarak jauh. Hasil penelitian menunjukkan bahwa pembelajaran daring memiliki dampak positif terhadap apek keterhubungan, aspek pembelajaran, dan aspek sosial (socio-emotional). Khusniyah dan Hakim (2019) melakukan penelitian terhadap efektivitas pembelajaran berbasis daring dengan memanfaatkan penggunaan web blog terhadap kemampuan mahasiswa dalam memahami teks berbahasa Inggris. Hasil penelitian menunjukkan bahwa adanya perbedaan kemampuan pemahaman mahasiswa. Selain itu, pembelajaran daring dengan web blog tersebut memberikan pengaruh positif terhadap peningkatan kemampuan membaca bahasa Inggris mahasiswa. Kuntarto (2017) melakukan penelitian terhadap keefektifan model pembelajaran daring dalam perkuliahan bahasa Indonesia dengan menggunakan teknik Online Interactive Learning Model (OILM). Hasil penelitian menunjukkan model pembelajaran ini mampu meningkatkan 
penyerapan materi kuliah oleh mahasiswa dengan peningkatan mencapai lebih dari $81 \%$. Rusdiana dan Nugroho (2020) melalukan penelitian terhadap respon mahasiswa pada pembelajaran daring mata kuliah pengantar hukum Indonesia dengan menggunakan e-learning VINESA UNESA. Hasil penelitian menunjukkan bahwa motivasi mahasiswa saat mengikuti perkuliahan daring sebesar $71 \%$ dan efektivitas perkuliahan sebesar 76,4\%. Mustofa, dkk. (2019) melakukan penelitian terhadap formulasi model perkuliahan daring dengan memanfaatkan situs resmi pemerintah sebagai upaya menekan disparitas kualitas perguruan tinggi. Hasil penelitian menunjukkan bahwa sistem kuliah daring memiliki kontribusi positif untuk mendorong disparitas kualitas perguruan tinggi di Indonesia. Maulana dan Hamidi (2020) telah melakukan penelitian terhadap persepsi mahasiswa terhadap pembelajaran daring pada mata kuliah praktik di pendidikan vokasi. Hasil penelitian menunjukkan bahwa mahasiswa memberikan persepsi positif untuk aspek proses belajar, kapabilitas dosen, dan sarana dan prasarana. Mustakim (2020) telah melakukan penelitian terkait efektivitas pembelajaran daring pada siswa kelas XI MIPA SMA Negeri Wajo pada mata pelajaran matematika. Hasil penelitian menunjukkan bahwa $23 \%$ peserta didik menilai pembelajaran matematika secara online sangat efektif, 46,7\% menilai efektif, $20 \%$ menilai biasa saja, dan $10 \%$ menilai tidak efektif.

Penelitian terdahulu semuanya berfokus pada dampak pembelajaran daring terhadap efektivitas pembelajaran, sedangkan penelitian terkait dampak pembelajaran daring terhadap psikologis mahasiswa masih belum dilakukan. Kemudian di masa pandemi COVID-19, tidak hanya satu atau dua mata kuliah yang dilaksanakan secara daring, tetapi semua mata kuliah harus dilaksanakan secara daring. Terlebih pada mata kuliah statistik bisnis, mengharuskan mahasiswa untuk berpikir kritis dalam menyelesaikan persoalan bisnis dengan menerapkan konsep-konsep statistika. Hal ini akan sangat sulit bagi mahasiswa tanpa adanya bimbingan secara langsung oleh dosen pengampu mata kuliah. Maka dari itu, penelitian ini bertujuan untuk mengetahui tingkat stres mahasiswa terhadap pembelajaran daring pada mata kuliah statistik bisnis di pendidikan vokasi pada masa pandemi COVID-19. Diharapkan dengan adanya penelitian ini dapat menjadi pertimbangan bagi tenaga pendidik dalam merancang pembelajaran daring. 


\section{METODE PENELITIAN}

Penelitian ini merupakan penelitian deskriptif kualitatif. Populasi pada penelitian ini adalah seluruh mahasiswa Program Sarjana Terapan Jurusan Administrasi Niaga Politeknik Negeri Bengkalis. Sampel diambil dengan menggunakan teknik purposive sampling yang hanya berfokus pada mahasiswa yang sedang mengambil mata kuliah Statistik Bisnis. Mahasiswa mendapatkan pembelajaran daring untuk mata kuliah statistika bisnis dimulai pada tanggal 27 Maret - 12 Juni 2020 yang dilakukan untuk menghindari penyebaran COVID-19. Perkuliahan daring dimulai pada pertemuan ke-6 hingga pertemuan ke-14 dengan menggunakan platform Google Classroom dan dilengkapi dengan video pembelajaran yang di unggah pada YouTube.

Data penelitian diperoleh dengan menggunakan kuesioner yang diisi secara daring oleh mahasiswa di akhir pertemuan ke-14 dengan menggunakan Google Form. Kuesioner yang digunakan mengadaptasi Instrumen DASS 42 yang dikeluarkan oleh Psychology Foundation of Australia dan telah diterjemahkan ke dalam bahasa Indonesia oleh Damanik (2006), Fakultas Psikologi Universitas Indonesia. Validitas dan reliabilitas instrumen telah diuji pada dua kelompok yang saling independen dengan total sampel 144 orang, dan dinyatakan valid dengan validitas terendah adalah 0,3532 , sedangkan nilai Reliabilitasnya adalah 0,9483 (Damanik, 2011). Kemudian dipilih item pernyataan yang sesuai untuk mengukur tingkat stres, yaitu pernyataan nomor $1,6,8,11,12,14,18,22,27,29,32,33,35,39$. Sehingga total item pernyataan untuk mengukur tingkat stres adalah 14 item. Responden diminta untuk memberikan responnya dengan menggunakan skala likert, yaitu: $0=$ tidak pernah, 1 = kadang-kadang, 2 = sering, $3=$ sering sekali. Selain itu juga digunakan wawancara mendalam kepada beberapa mahasiswa untuk mendapatkan informasi yang lebih mendetail.

Teknik analisis data yang digunakan dalam penelitian ini adalah analisis kualitatif yang terdiri atas pengumpulan data, reduksi data, penyajian data, dan penarikan kesimpulan. Interpretasi tingkat stres yang dialami mahasiswa dalam penelitian ini mengacu pada standar pengukuran DASS, seperti pada Tabel 1. 
Tabel 1. Interpretasi instrumen DASS 42

\begin{tabular}{cc}
\hline Kategori & Stres \\
\hline Normal & $0-14$ \\
Ringan & $15-18$ \\
Sedang & $19-25$ \\
Berat & $26-33$ \\
Sangat berat & $34+$ \\
\hline
\end{tabular}

Sumber: Lovibond, S.H. \& Lovibond, P.F. (1995)

\section{HASIL DAN PEMBAHASAN}

Pembelajaran daring mata kuliah statistik bisnis dilakukan menggunakan platform Google Classroom dengan kode nty3j7j yang dilakukan mulai pertemuan ke-6 hingga pertemuan ke-14. Setelah pertemuan ke-14 mahasiswa diminta mengisi kuesioner secara daring. Adapunidentitas responden dapat dilihat pada Tabel 2.

Tabel 2. Identitas Responden

\begin{tabular}{|c|c|c|}
\hline Karakteristik & Jumlah (orang) & Persentase (\%) \\
\hline Jenis Kelamin & & \\
Laki-laki & 9 & 14 \\
Perempuan & 51 & 86 \\
\hline Usia & 4 & 7 \\
17 & 14 & 23 \\
18 & 36 & 60 \\
19 & 6 & 10 \\
20 &
\end{tabular}

Sumber: data olahan 2020

Berdasarkan Tabel 2 terlihat bahwa responden terdiri atas 9 orang lakilaki dengan proporsi $14 \%$ dan 51 orang perempuan dengan proporsi $86 \%$. Responden berusia di antara 17 - 20 tahun dengan proporsi $7 \%$ berusia 17 tahun, $23 \%$ berusia 18 tahun, $60 \%$ berusia 19 tahun, dan $10 \%$ berusia 20 tahun.Adapun tingkat kehadiran mahasiswa dan materi pada pembelajaran daring ditunjukkan pada Tabel 3. 
Tabel 3. Materi Perkuliahan dan Tingkat Kehadiran Mahasiswa

\begin{tabular}{|c|c|c|c|c|}
\hline \multirow[b]{2}{*}{$\begin{array}{l}\text { Pertemuan } \\
\text { Ke- }\end{array}$} & \multirow[b]{2}{*}{ Materi Perkuliahan } & \multicolumn{2}{|c|}{ Kehadiran* } & \multirow[b]{2}{*}{$\begin{array}{c}\text { Total } \\
(\%)\end{array}$} \\
\hline & & $\begin{array}{l}\text { Hadir } \\
(\%)\end{array}$ & $\begin{array}{l}\text { Tidak Hadir } \\
(\%)\end{array}$ & \\
\hline 6 & Discrete Random Variables: & $61(100)$ & $0(0)$ & $61(100)$ \\
\hline 7 & $\begin{array}{l}\text { Review (All problem from week } \\
1-6 \text { ) }\end{array}$ & $61(100)$ & $0(0)$ & $61(100)$ \\
\hline 8 & $\begin{array}{l}\text { Continuous Probability } \\
\text { Distribution }\end{array}$ & $61(100)$ & $0(0)$ & $61(100)$ \\
\hline 9 & $\begin{array}{l}\text { Hypothesis Tests 1: } \\
\text { 1. Developing Null and } \\
\text { Alternative Hypotheses } \\
\text { 2. Type I and Type II Errors } \\
\text { 3. Population Mean : } \sigma \text { Known }\end{array}$ & $61(100)$ & $0(0)$ & $61(100)$ \\
\hline 10 & $\begin{array}{l}\text { Hypothesis Tests 1: } \\
\text { 4. Population Mean: } \sigma \\
\text { Unknown }\end{array}$ & $61(100)$ & $0(0)$ & $61(100)$ \\
\hline 11 & $\begin{array}{l}\text { Hypothesis Tests 2: } \\
\text { 1. Population Mean: Matched } \\
\text { Pairs }\end{array}$ & $61(100)$ & $0(0)$ & $61(100)$ \\
\hline 12 & $\begin{array}{l}\text { Hypothesis Tests 2: } \\
\text { 2. Population Mean: } \\
\text { Independent Samples }\end{array}$ & $61(100)$ & $0(0)$ & $61(100)$ \\
\hline 13 & $\begin{array}{l}\text { Simple Linier Regression: } \\
\text { 1. Types of regression models } \\
\text { 2. Determining the simple linier } \\
\text { regression equation }\end{array}$ & $61(100)$ & $0(0)$ & $61(100)$ \\
\hline 14 & $\begin{array}{l}\text { Review (All problem from week } \\
8-13 \text { ) }\end{array}$ & $61(100)$ & $0(0)$ & $61(100)$ \\
\hline
\end{tabular}

Sumber: *Biro Administrasi Akademik, 2020

Berdasarkan Tabel 3 terlihat bahwa tingkat kehadiran mahasiswa pada pembelajaran daring mata kuliah statistik bisnis adalah 100\%. Setelah pertemuan ke-14 mahasiswa diminta mengisi kuesioner secara daring yang merupakan mahasiswa Jurusan Administrasi Niaga dari Program Studi Sarjana Terapan Administrasi Bisnis Internasional (ABI) semester II (dua) Kelas A dan B. Selanjutnya responden mengisi kuesioner Instrumen DASS 42 terdiri atas 42 pernyataan. Namun yang digunakan untuk mengukur tingkat stres 
hanya terdiri atas 14 pernyataan. Setiap butir pernyataan menggunakan skala ordinal berupa skala likert, yaitu: $0=$ tidak pernah, $1=$ kadang-kadang, $2=$ sering, 3 = sering sekali. Hasil kuesioner dapat dilihat pada Tabel 4.

Tabel 4. Hasil Pengisian Kuesioner Tingkat Stres oleh Responden

\begin{tabular}{|c|c|c|c|c|c|c|c|c|c|}
\hline No & Pornyatoan & & & 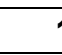 & & 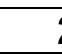 & & 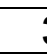 & \\
\hline No. & remlindadan & $f$ & $\%$ & $f$ & $\%$ & $f$ & $\%$ & $f$ & $\%$ \\
\hline 1 & $\begin{array}{l}\text { Saya merasa bahwa diri saya menjadi } \\
\text { marah karena hal-hal sepele. }\end{array}$ & 12 & 20 & 34 & 56 & 13 & 22 & 1 & 2 \\
\hline 2 & $\begin{array}{l}\text { Saya cenderung bereaksi berlebihan } \\
\text { terhadap suatu situasi. }\end{array}$ & 20 & 33 & 30 & 50 & 7 & 12 & 3 & 5 \\
\hline 3 & Saya merasa sulit untuk bersantai. & 14 & 23 & 23 & 39 & 15 & 25 & 8 & 13 \\
\hline 4 & $\begin{array}{l}\text { Saya menemukan diri saya mudah } \\
\text { merasa kesal. }\end{array}$ & 12 & 20 & 29 & 48 & 15 & 25 & 4 & 7 \\
\hline 5 & $\begin{array}{l}\text { Saya merasa telah menghabiskan } \\
\text { banyak energi untuk merasa cemas. }\end{array}$ & 15 & 25 & 31 & 51 & 10 & 17 & 4 & 7 \\
\hline 6 & $\begin{array}{l}\text { Saya menemukan diri saya menjadi } \\
\text { tidak sabar ketika mengalami } \\
\text { penundaan }\end{array}$ & 11 & 18 & 29 & 49 & 15 & 25 & 5 & 8 \\
\hline 7 & $\begin{array}{l}\text { Saya merasa bahwa saya mudah } \\
\text { tersinggung. }\end{array}$ & 21 & 35 & 23 & 39 & 11 & 18 & 5 & 8 \\
\hline 8 & Saya merasa sulit untuk beristirahat. & 14 & 23 & 31 & 52 & 6 & 10 & 9 & 15 \\
\hline 9 & $\begin{array}{l}\text { Saya merasa bahwa saya sangat } \\
\text { mudah marah. }\end{array}$ & 14 & 23 & 25 & 42 & 14 & 23 & 7 & 12 \\
\hline 10 & $\begin{array}{l}\text { Saya merasa sulit untuk tenang setelah } \\
\text { sesuatu membuat saya kesal. }\end{array}$ & 15 & 25 & 24 & 40 & 12 & 20 & 9 & 15 \\
\hline 11 & $\begin{array}{l}\text { Saya sulit untuk sabar dalam } \\
\text { menghadapi gangguan terhadap hal } \\
\text { yang sedang saya lakukan. }\end{array}$ & 18 & 30 & 26 & 44 & 11 & 18 & 5 & 8 \\
\hline 12 & Saya sedang merasa gelisah. & 32 & 53 & 17 & 29 & 8 & 13 & 3 & 5 \\
\hline 13 & $\begin{array}{l}\text { Saya tidak dapat memaklumi hal apapun } \\
\text { yang menghalangi saya untuk } \\
\text { menyelesaikan hal yang sedang saya } \\
\text { lakukan. }\end{array}$ & 24 & 40 & 22 & 37 & 11 & 18 & 3 & 5 \\
\hline 14 & $\begin{array}{l}\text { Saya menemukan diri saya mudah } \\
\text { gelisah. }\end{array}$ & 31 & 52 & 20 & 33 & 6 & 10 & 3 & 5 \\
\hline
\end{tabular}

Sumber: Data olahan, 2020

Berdasarkan 14 pernyataan tersebut, mahasiswa dikelompokkan menurut tingkat stres berdasarkan interpretasi instrumen DASS 42 ke dalam lima 
kategori, yaitu: normal, ringan, sedang, berat, dan sangat berat. Hasil interpretasi tingkat mahasiswa dapat dilihat pada Tabel 5.

Tabel 5. Hasil Interpretasi Tingkat Stres Responden

\begin{tabular}{|c|c|c|}
\hline Kategori & Jumlah (orang) & Persentase (\%) \\
\hline Normal & 31 & 52 \\
\hline Ringan & 14 & 24 \\
\hline Sedang & 5 & 8 \\
\hline Berat & 8 & 13 \\
\hline Sangat Berat & 2 & 3 \\
\hline TOTAL & 60 & 100 \\
\hline
\end{tabular}

Sumber: Data olahan SPSS, 2020

Berdasarkan Tabel 5 terlihat bahwa setelah mengikuti perkuliahan daring mata kuliah statistik bisnis terlihat bahwa mayoritas tingkat stres mahasiswa masih dalam keadaan normal yaitu sebesar 52\%, tingkat stres ringan sebesar $24 \%$, tingkat stres sedang sebesar $8 \%$, tingkat stres berat sebesar $13 \%$, dan tingkat stres sangat berat sebesar 3\%. Hasil wawancara dengan mahasiswa yang memiliki tingkat stres normal menunjukkan bahwa mahasiswa tidak terbebani dengan perkuliahan secara daring dikarenakan pembelajaran dilengkapi dengan penjelasan berupa video. Selain itu juga tenggat waktu untuk mengumpulkan tugas yang sudah tepat sehingga mahasiswa tidak merasa tertekan. Hal ini berdasarkan pernyataan Mahasiswa_26 yang mengatakan bahwa:

"Saya rasa dan saya hadapi saat ini yaitu proses perkuliahan statistik bisnis secara online berjalan dengan baik, materi yang saya dapatkan juga lengkap. Sarannya saya rasa semoga dapat belajar statistik seperti kegiatan biasa yaitu secara tatap muka. Amiin"

Mahasiswa_60 juga mengatakan bahwa:

"Waktu tenggang yang baik untuk menyelesaikan tugas yang diberikan sangat baik dan lancar dalam melakukan perkuliahan daring".

Selain itu juga ternyata mahasiswa dengan tingkat stres normal juga mengalami beberapa kendala dalam mengikuti pembelajaran daring, yaitu belum terbiasa dengan sistem daring. Hal ini berdasarkan pernyataan 
Mahasiswa_18 yang mengatakan bahwa:

"Jujur kalau saya sangat kurang paham kalau menggunakan online karena bagi saya statistik lumayan susah tapi dengan dibantu teman dan ada video sedikit membantu saya".

Kemudian hasil wawancara dengan mahasiswa yang memiliki tingkat stres ringan menunjukkan bahwa mahasiswa mengalami sedikit stres karena adanya perubahan kebiasaan pembelajaran dilakukan secara mandiri tanpa adanya interaksi sosial dengan mahasiswa yang lain. Hal ini berdasarkan pernyataan Mahasiswa_9 yang mengatakan bahwa:

"Menurut saya ini terjadi karena hanya perubahan kebiasaan yang terjadi pada mahasiswa. Awalnya mungkin disambut dengan baik karena menjadi sesuatu yang berbeda, namun setelah dijalankan justru membuat para mahasiswa kembali jenuh dengan rutinitas yang harus dilakukan setiap hari tersebut secara daring dan sendirian".

Selanjutnya hasil wawancara dengan mahasiswa yang memiliki tingkat stres sedang menunjukkan bahwa mahasiswa mengalami stres karena fasilitas pendukung pembelajaran yang dimiliki oleh mahasiswa tidak mendukung pembelajaran daring sehingga kegiatan pembelajaran tidak dapat terselenggara dengan baik. Hal ini sesuai dengan pernyataan Mahasiswa_23 yang mengatakan bahwa:

"Kuliah online memang bagus saat seperti ini, tetapi juga mengakibatkan masalah ketika fasilitas pendukung tidak ada".

Hasil wawancara dengan mahasiswa yang memiliki tingkat stres berat menunjukkan bahwa mahasiswa mengalami stres karena kesulitan dalam memahami materi perkuliahan secara daring. Hal ini berdasarkan pernyataan Mahasiswa_29 yang mengatakan bahwa:

"Secara daring ini saya banyak kurang paham pak".

Kemudian hasil wawancara dengan mahasiswa yang memiliki tingkat stres sangat berat menunjukkan bahwa mahasiswa mengalami stres karena kesulitan dalam memahami materi. Kesulitan yang dialami bukan dikarenakan pembelajaran daring yang dilakukan. Hal ini berdasarkan pernyataan Mahasiswa_51. 
Selye (1975) mengatakan bahwa respon tubuh terhadap stres adalah bersifat universal, tanpa melihat stres yang dialami secara eksternal atau internal. Respon ini dikenal sebagai Sindrom Adaptasi Umum (GAS). Model GAS terbagi menjadi tiga fase, yaitu fase alarm, fase resistansi, dan fase keletihan. Fase alarm dapat terjadi di awal pengumuman penghentian pembelajaran tatap muka dan dilanjutkan dengan pembelajaran daring yang dimulai pada pertemuan ke-6. Pada fase ini mahasiswa mulai mengetahui adanya stressor berupa untuk mengikuti pembelajaran daring harus memiliki perangkat pendukung yang memadai, seperti laptop atau smartphone dan paket data untuk dapat mengikuti pembelajaran. Fase tersebut berlanjut ke fase resistensi seiring dengan pembelajaran daring yang dilakukan. Melalui pembelajaran daring mahasiswa dituntut untuk belajar secara mandiri dan sendiri, sehingga aspek sosial menghilang dari proses pembelajaran. Pada pembelajaran tatap muka mahasiswa dapat berinteraksi sosial dengan rekan mahasiswa dan dapat berinteraksi langsung dengan dosen pengampu mata kuliah. Namun hal ini tidak dapat dirasakan oleh mahasiswa pada pembelajaran daring. Seiring berjalannya waktu mahasiswa beradaptasi dengan berbagai mekanisme sehingga tingkat hormon terkait stres berangsur normal. Hal inilah yang memungkinkan 52\% tingkat stres mahasiswa berada pada kategori normal. Namun bagi mahasiswa yang tidak mampu beradaptasi dengan pembelajaran daring akan menyebabkan tingkat hormon terkait stres akan meningkat seiring dengan pelaksanaan pembelajaran daring. Sehingga hal inilah yang memungkinkan $48 \%$ tingkat stres mahasiswa berada pada kategori di atas normal.

\section{Tingkat Stres Mahasiswa berdasarkan Jenis Kelamin}

Hasil penelitian menunjukkan bahwa tingkat stres berdasarkan jenis kelamin mahasiswa semester II Program Studi Administrasi Bisnis Internasional Politeknik Negeri Bengkalis untuk mahasiswa laki-laki sebesar $56 \%$ pada kategori normal, 22\% pada kategori ringan, dan 22\% pada kategori sangat berat. Sedangkan mahasiswa perempuan sebesar $51 \%$ pada kategori normal, $23 \%$ pada kategori ringan, $10 \%$ pada kategori sedang, dan $16 \%$ pada kategori berat. Adapun distribusi tingkat stres mahasiswa berdasarkan jenis kelamin dapat dilihat pada Tabel 6. 
Tabel 6. Distribusi Tingkat Stres Responden Berdasarkan Jenis Kelamin

\begin{tabular}{cccc}
\hline \multirow{2}{*}{ Kategori } & \multicolumn{2}{c}{ Jenis kelamin } & p-value \\
\cline { 2 - 3 } & Laki-laki $(\%)$ & Perempuan (\%) & \\
\hline Normal & $5(56)$ & $26(51)$ & \\
Ringan & $2(22)$ & $12(23)$ & $0,008^{*}$ \\
Sedang & $0(0)$ & $5(10)$ & \\
Berat & $0(0)$ & $8(16)$ & \\
Sangat Berat & $2(22)$ & $0(0)$ & \\
\hline TOTAL & $9(100)$ & $51(100)$ & \\
\hline
\end{tabular}

*Uji Chi-Square

Sumber: Data olahan SPSS, 2020

Berdasarkan hasil uji Chi Square diperoleh p-value sebesar 0,008 sehingga dapat disimpulkan bahwa terdapat pengaruh jenis kelamin terhadap tingkat stres mahasiswa dengan taraf signifikansi $\alpha$ sebesar 5\%. Pada penelitian ini terlihat bahwa jumlah persentase mahasiswa perempuan yang memiliki tingkat stres di atas normal lebih tinggi dibandingkan dengan mahasiswa laki-laki. Oleh karena itu dapat disimpulkan bahwa tingkat stres mahasiswa pada pembelajaran daring mata kuliah statistik bisnis dipengaruhi oleh jenis kelamin mahasiswa. Charbonneau (2009) melakukan penelitian terhadap 315 remaja menunjukkan bahwa jenis kelamin merupakan prediktor signifikan dari reaktivitas emosional, perempuan cenderung memiliki tingkat stres yang lebih tinggi dibandingkan laki-laki.

\section{Tingkat Stres Mahasiswa Berdasarkan Usia}

Hasil penelitian menunjukkan bahwa tingkat stres berdasarkan usia mahasiswa semester II Program Studi Administrasi Bisnis Internasional Politeknik Negeri Bengkalis untuk mahasiswa berusia 17 tahun sekitar $75 \%$ memiliki tingkat stres di atas normal, usia 18 tahun sebanyak 43\%, usia 19 tahun sebanyak 47\%, dan usia 20 tahun sebanyak 50\%. Adapun distribusi tingkat stres mahasiswa berdasarkan usia dapat dilihat pada Tabel 7. 
Tabel 7. Distribusi Tingkat Stres Responden Berdasarkan Usia

\begin{tabular}{cccccc}
\hline \multirow{2}{*}{ Kategori } & \multicolumn{4}{c}{ Usia (Tahun) } & \multirow{2}{*}{-value } \\
\cline { 2 - 5 } & $\mathbf{1 7 ( \% )}$ & $\mathbf{1 8 ( \% )}$ & $\mathbf{1 9}(\boldsymbol{\%})$ & $\mathbf{2 0}(\boldsymbol{\%})$ & \\
\hline Normal & $1(25)$ & $8(57)$ & $19(53)$ & $3(50)$ & \\
Ringan & $2(50)$ & $2(14)$ & $8(22)$ & $2(33)$ & \\
Sedang & $0(0)$ & $2(14)$ & $3(8)$ & $0(0)$ & $0,921^{*}$ \\
Berat & $1(25)$ & $1(7)$ & $5(14)$ & $1(17)$ & \\
Sangat Berat & $0(0)$ & $1(7)$ & $1(3)$ & $0(0)$ & \\
\hline TOTAL & $4(100)$ & $14(100)$ & $36(100)$ & $6(100)$ & \\
\hline
\end{tabular}

*Uji Chi-Square

Sumber: Data olahan SPSS, 2020

Berdasarkan hasil uji Chi Square diperoleh p-value sebesar 0,921 maka dapat disimpulkan bahwa tidak terdapat pengaruh usia terhadap tingkat stres mahasiswa pada rentang usia 17-20 tahun. Sehingga pada penelitian ini tingkat stres mahasiswa pada pembelajaran daring mata kuliah statistik bisnis tidak dipengaruhi oleh usia mahasiswa.

\section{SIMPULAN}

Berdasarkan hasil penelitian dapat disimpulkan bahwa pembelajaran daring mata kuliah statistik bisnis mengakibatkan 3\% mahasiswa memiliki tingkat stres kategori sangat berat, 13\% kategori berat, $8 \%$ kategori sedang, $24 \%$ kategori ringan, dan 52\% dalam kategori normal. Tingkat stres yang dialami mahasiswa dipengaruhi oleh jenis kelamin mahasiswa, sedangkan usia mahasiswa dengan rentang usia 17-20 tahun tidak mempengaruhi tingkat stres. Penelitian ini hanya berfokus pada tingkat stres yang dialami mahasiswa, sedangkan instrumen DASS 42 juga mampu mengukur tingkat depresi dan kecemasan. Oleh karena itu disarankan untuk dilakukan pembahasan lebih lanjut terkait tingkat depresi dan kecemasan mahasiswa. Selain itu juga perlu dilakukan penelitian lanjutan terkait faktor-faktor lain yang mempengaruhi tingkat stres mahasiswa. 


\section{DAFTAR PUSTAKA}

Charbonneau, A. M., Mezulis, A. H., \& Hyde, J. S. 2009. Stress and emotional reactivity as explanations for gender differences in adolescents' depressive symptoms. Journal of youth and adolescence, 38(8), 10501058.

Damanik, D. E. 2006. Pengujian Realibilitas, Validitas, Analisis Item, dan Pembuatan Norma Depression, Anxiety and Stress Scale (DASS). Faculty of Psychology, University of Indonesia, Indonesia.

Khusniyah, N., \& Hakim, L. 2019. Efektivitas Pembelajaran Berbasis Daring: Sebuah Bukti pada Pembelajaran Bahasa Inggris. Jurnal Tatsqif, 17(1), 19-33.

Kuntarto, E. 2017. Keefektifan Model Pembelajaran Daring dalam Perkuliahan Bahasa Indonesia di Perguruan Tinggi. Journal Indonesian Language Education and Literature, 3(1), 99-110.

Lovibond, S.H. \& Lovibond, P.F. 1995. Manual for the Depression Anxiety Stress Scales 2nd. Ed. Sydney: Psychology Foundation. ISBN 73341423-0.

Maulana, H. A., \& Hamidi, M. 2020. Persepsi Mahasiswa terhadap Pembelajaran Daring pada Mata Kuliah Praktik di Pendidikan Vokasi. Equilibrium: Jurnal Pendidikan, 8(2), 224-231.

Mustakim, M. 2020. Efektivitas Pembelajaran Daring Menggunakan Media Online Selama Pandemi Covid-19 Pada Mata Pelajaran Matematika. Al asma: Journal of Islamic Education, 2(1), 1-12.

Mustofa, M. I., Chodzirin, M., \& Sayekti, L. 2019. Formulasi Model Perkuliahan Daring Sebagai Upaya Menekan Disparitas Kualitas Perguruan Tinggi (Studi terhadap Website pditt. belajar. kemdikbud. go.id). Walisongo Journal of Information Technology, 1(2), 151-160.

Rusdiana, E., \& Nugroho, A. 2020. Respon pada Pembelajaran Daring bagi Mahasiswa Mata Kuliah Pengantar Hukum Indonesia. INTEGRALISTIK, 31(1),1-12

Selye, H. 1975. Stress without distress. NewYork: Signet Books.

Tantri, N. R. 2018. Kehadiran Sosial dalam Pembelajaran Daring Berdasarkan Sudut Pandang Pembelajar Pendidikan Terbuka dan Jarak Jauh. Jurnal Pendidikan Terbuka dan Jarak Jauh, 19(1), 19-30. 